\title{
ENHANCING THE PRODUCTIVITY OF DEGRADED LAND THROUGH SOIL AND WATER CONSERVATION TECHNIQUE IN CARITA RESEARCH FOREST, WEST JAVA
}

\author{
Pratiwi ${ }^{1,2}$ and Budi Hadi Narendra ${ }^{1}$ \\ Received : 12 April 2010, Accepted : 21 September 2012
}

\begin{abstract}
Encroachments on Carita Research Forest area have exacerbated the degradation of land due to uncontrolled runoff, erosion and nutrient losses especially on the sloping land with high annual rainfall. To reduce the severity of the degradation the area should be rehabilitated by applying soil and water conservation techniques. The techniques used were the vegetative methods (culture), and a combination of it with mechanical/technical methods. The combination method is expected to be more effective in controlling runoff, erosion and nutrient losses. One important parameter is the efficiency of the distance of the vertical mulch channel, which affects the application cost. This study was aimed to determine the effect of different distances of vertical mulch channels on the plant growth and annual crop yield as well as its effectiveness in controlling runoff, erosion and nutrient losses. The research was conducted in Carita Research Forest from 2005 to 2008, using the randomized block design. Treatments applied were: vertical mulch with six and twelve meter distances of plots of khaya (Khaya anthotheca C.Dc.) and corn (Zea mays L.) cropping system. Observations included height and diameter growth of khaya, runoff and erosion, and cost per ha. The results showed that six meter of vertical mulch was the most efficient distance. The height and diameter of khaya tree increased by $7 \%$ and $31 \%$ in six meter distance compared to the control. Moreover, runoff and erosion was reduced by $75 \%$ and $37 \%$, and nutrient losses could be trimmed down by three to five times. In addition, six meters distance could also produce corn of $712 \mathrm{~kg} / \mathrm{ha} /$ year, which was $73 \%$ greater than corn production without vertical mulch. On the other hand, the cropping system with six meter distance of vertical mulch required Rp 3,250,000,- per ha, which was Rp 250,000,--more expensive than that without vertical mulch.
\end{abstract}

Keywords: Khaya anthotheca, runoff, erosion, soil and water conservation, vertical mulch

\section{INTRODUCTION}

Encroachments on Carita Research Forest area have led to increase in area of bare land. This land is generally characterized by slopes of more than 20 compounded by high annual rainfall. Areas with such conditions are particularly vulnerable to uncontrolled runoff, erosion, and nutrient losses that will lower land productivity. Soil damage, especially on the surface layer is characterized by

\footnotetext{
${ }^{1}$ Center for Forest Conservation and Rehabilitation Research and Development, Forestry Research and Development Agency, Jl. Gunung Batu No. 5 Bogor

2Corresponding author:pratiwi.lala@yahoo.com
}

low level of organic matter, reduction in infiltration rate, and a decrease in the number of macro pore spaces. On this bare land, organic matter content will continue to decline due to the faster decay process, will be lost by erosion, and exacerbated by the lack of vegetation litter as an additional source of soil organic matter. On this bare land, higher runoff and erosion rate can occur compared to the previously covered land. Accumulation of these conditions on a large scale can be a trigger of hydro-geological disasters such as flood and landslide (Widianto et al., 2004).

To reduce the severity of degraded land, the area should be rehabilitated by implementing soil and water conservation techniques. In practice, 
application of soil and water conservation technique can be done not only through vegetative method (culture), but also it can be combined with mechanical methods. The combination of mechanical-culture method is more effective in controlling the runoff and erosion, and can maintain soil fertility. Rehabilitation of degraded land requires more attention, especially in the rehabilitation of unvegetated sloping land, coupled with relatively high annual rainfall because there is a condition/critical period when the plant canopy closure rate is still low, despite the land being planted with trees in the early years (Dariah $e t$ al., 2004). Application of technical culture method in the forest rehabilitation of Carita was expected to suppress the rate of runoff and erosion, and also be able to reduce soil nutrient losses so the plants could grow and provide better results.

The aim of this study was to find out the effectiveness of technical culture method of soil and water conservation in suppressing the runoff, erosion, and nutrient loss in the area of Carita Research Forest (CRF). The study used Khaya (Khaya anthotheca C.Dc.) as the main species and corn (Zea mays L.) as an annual crop. Khaya is a potential exotic species developed in Indonesia through introduction in West Java. The growth of Khaya anthotheca was observed at six planting sites in West Java i.e. Pasir Hantap, Cikampek, Pasir Awi, Cikole, Carita, and Yanlappa. It could be concluded that Khay a anthotheca generally grew well in West Java. On CRF site, the growth is relatively very fast because of the compatibility between the growing requirements with the ecological conditions (Mindawati and Tiryana, 2002). Its high survival rate and good growth has made Khaya anthotheca a species that can be relied upon in the rehabilitation of degraded land in the CRF. Based on this adaptation to the site and the introduction to the public, it will increase the chances of successful rehabilitation efforts (Pratiwi, 2000).

In this research, culture method was used combined with the mechanical method using vertical mulch. The technique utilizes organic waste from litter, weeds, branches, twigs, stems and leaves of land-clearing waste by entering them into a channel that was made across the slope. Application of vertical mulch is usually supported by a soil ridge to reduce runoff velocity before the water entering into the vertical mulch channels. Ecologically, this technique is proven to reduce the rate of runoff, erosion, and loss of nutrients. Runoff will flow into the channel containing mulch (forest waste), then infiltrates into the soil profile. Organic material in the form of mulch is a medium that can absorb and hold large amounts of water mass, so that water storage in the soil can be improved (Pratiwi, 2000). However, the consequences of the application of this technique is that it needs additional costs/resources for its construction, especially for channel digging, therefore the determination of the channel distance (interval) should be optimally decided.

\section{MATERIAL AND METHODS}

\section{A. Research Site}

The research was conducted at Carita Research Forest, which is 50 ha large and is located around $200 \mathrm{~km}$ from Bogor. This site is located between $06^{\circ} 8^{\prime}-06^{\circ} 14^{\prime}$ south latitude and $105^{\circ} 50^{\prime}-105^{\circ} 55^{\prime}$ east longitude in Labuan Sub District, Pandeglang District, West Jawa Province. Based on Schmidt and Ferguson (1951) classification, it has type A climate with $3959 \mathrm{~mm}$ average annual rainfall. The dominant soil type is dark gray alluvial soil with clay sediment as parent material (Balai Penelitian Tanah, 1996). The area is dominated by hilly topography and the research site was located at about $100 \mathrm{~m}$ a.s.l. elevation with a $20^{\circ}$ slope. The research was conducted from 2005 to 2008.

\section{B. Materials}

Materials and tools used in this research were Khaya seedlings, corn seeds, NPK fertilizer, bricks, cement, sand, pipes, sampling bottles, black plastic sheets, hoes, machetes, poles, measuring tape, caliper, digital balance, oven, porcelain dishes and builder equipments.

\section{Methods}

The research was started by establishing nine experiment plots of $20 \times 20 \mathrm{~m}$ each. Randomized block design was used with three treatments and three replications. The treatments were: 
P0 = khaya + corn + without vertical mulch (as control)

P6 = khaya + corn + vertical mulch with $6 \mathrm{~m}$ distance

P12 = khaya + corn + vertical mulch with $12 \mathrm{~m}$ distance

Vertical mulch channels were dug across the slope and the distance between the channals was adjusted to the size of the channel, which was 60 $\mathrm{cm}$ in depth and $20 \mathrm{~cm}$ in width. Excavated soil from digging of channels was used to make soil ridge on the upper part of the channel with $40 \mathrm{~cm}$ width and $40 \mathrm{~cm}$ height. Organic waste was placed into the channels. Corn was planted on the area between vertical mulches with a spacing of $20 \times 20$ $\mathrm{cm}$. Khaya seedlings were planted on the soil ridge, also on the corn crop area using $3 \times 3 \mathrm{~m}$ planting distance and $50 \times 50 \times 50 \mathrm{~cm}$ planting holes. NPK fertilizer (Phonska) was applied as a basic treatment for all Khaya seedlings at a dose of $25 \mathrm{~g} /$ planting hole.

A runoff-erosion measurement tool (erosion plot) was constructed in each plot. The size of each erosion plot was $4 \times 20 \mathrm{~m}$ and it was equipped with a water collector on the lower part. The collector was made of masonry with a length, width, and depth of 200,100, and $150 \mathrm{~cm}$ respectively and was covered so that rain water did not enter directly into it. Barrier around the erosion plot was built using heap of soil and covered with black plastic sheet.

The variables measured in the research included the height and diameter of khaya species, erosion, runoff, nutrient losses due to erosion and runoff, and yield of the corn. Stem height and diameter measurements were done during three years using a measuring tape and caliper. Measurements of runoff and erosion were done during the first year and were carried out in the morning after every rainfall by recording the amount of water in the collector and taking water samples from each collector. Erosion rate was measured using evaporation method. In this method, water samples were put into porcelain dishes, placed into oven for evaporation than the remaining sediment were weighed to calculate erosion occurred in each treatment.

Chemical analyzes for sediment and water samples were done to determine the types and amount of nutrient losses through erosion and runoff processes. Corn yield for one year was weighed for each treatment. Costs required for Khaya planting was recorded and calculated for each treatment. The cost components included Khaya seedling, corn seed, NPK fertilizer, farm equipment, labour cost of each stage of activities, and others.

\section{Data Analysis}

To evaluate treatment effects on the height and diameter growth rates of the khaya, Analysis of Variance (ANOVA) was performed with the following mathematical model:

$$
\begin{aligned}
\mathrm{Y}_{\mathrm{i}, \mathrm{k}} & =\mu+\mathrm{P}_{\mathrm{i}}+\mathrm{K}_{\mathrm{i}}+\varepsilon_{\mathrm{ijk}} \\
\mathrm{Y}_{\mathrm{i} \mathrm{j} \mathrm{k}} & =\text { observed variable } \\
\mu & =\text { overall mean } \\
\mathrm{P}_{\mathrm{i}} & =\text { effect of treatment } \mathrm{i} \\
\mathrm{K}_{\mathrm{i}} & =\text { effect of block } \mathrm{j} \\
\varepsilon_{\mathrm{i}, \mathrm{k}} & =\text { random error }
\end{aligned}
$$

The analysis of result which showed significant effect of the treatment was continued by a Least Significant Difference (LSD) test for post hoc treatment comparison. The differences were considered significant at $\mathrm{P}<0.05$. The data of erosion, runoff, nutrient losses, and cost needed were analyzed by tabulation to find out simple comparisons among the treatments.

\section{RESULT AND DISCUSSION}

\section{A. Height and Diameter Growth of Khaya}

Height and diameter measurements of khaya up to three years are shown in Figure 1. The figure indicates that vertical mulch application with $6 \mathrm{~m}$ distance (P6) generally resulted in the highest height and diameter growth in each year. 

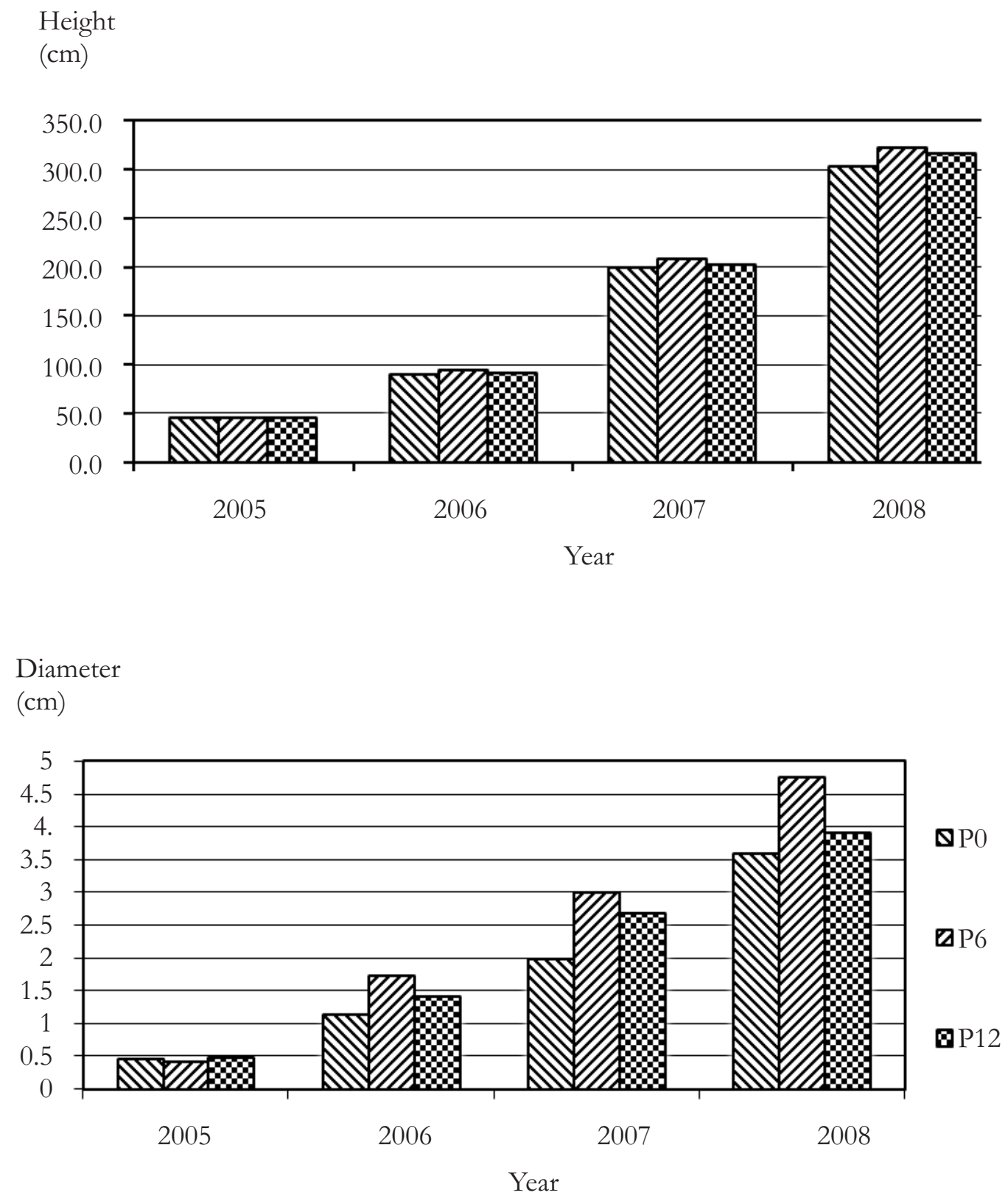

Figure 1. Height and diameter growth of khaya after three years

The highest stem height was found in P6 treatment and the lowest was in P0. The same result was also found for diameter growth even with bigger differences. In the last measurement, P6 treatment resulted in $7 \%$ and $2 \%$ higher hight growth compared to P0 and P12 treatments respectively. As regards diameter growth P6 resulted in $32 \%$ and $22 \%$ higher growth rates compared with $\mathrm{P} 0$ and P12 respectively. Details of the differences in height and diameter for each year were calculated by growth and statistical analysis.

Height and diameter growth were found by subtracting the height and diameter in a given year from the previous year, as listed in Table 1. 
Table 1. Height and diameter growth after three years

\begin{tabular}{|c|c|c|c|c|}
\hline \multirow{2}{*}{ Treatment } & \multicolumn{3}{|c|}{ Height growth $(\mathrm{cm})$} & \multirow{2}{*}{$\begin{array}{l}\text { Mean annual increment } \\
(\mathrm{cm} / \mathrm{yr})\end{array}$} \\
\hline & $1^{\text {st }}$ year & $2^{\text {nd }}$ year & $3^{\text {rd }}$ year & \\
\hline $\mathrm{P}_{0}$ & 44.5 & 109.5 & 103.2 & 100.8 \\
\hline $\mathrm{P}_{6}$ & 49.4 & 113.4 & 114.1 & 107.4 \\
\hline $\mathrm{P}_{12}$ & 46.6 & 111.3 & 113.2 & 105.4 \\
\hline \multirow[t]{3}{*}{ Average } & 46.8 & 111.4 & 110.2 & 104.5 \\
\hline & \multicolumn{3}{|c|}{ Diameter growth $(\mathrm{cm})$} & Mean annual increment \\
\hline & $1^{\text {st }}$ year & $2^{\text {nd }}$ year & $3^{\text {rd }}$ year & $(\mathrm{cm} / \mathrm{yr})$ \\
\hline $\mathrm{P}_{0}$ & 0.66 & 0.85 & 1.62 & 1.20 \\
\hline $\mathrm{P}_{6}$ & 1.29 & 1.27 & 1.77 & 1.59 \\
\hline $\mathrm{P}_{12}$ & 0.93 & 1.28 & 1.21 & 1.30 \\
\hline Average & 0.96 & 1.13 & 1.53 & 1.36 \\
\hline
\end{tabular}

Height of Khaya increased in every year but the average height growth was not equal for each year. The biggest increment has occurred in the second year with $111.4 \mathrm{~cm}$ on the average. Up to the third year, the average height of khaya in the P6 treatment has reached seven times its initial height, and for the diameter P6 treatment has reached eleven times its initial diameter. In the third year, diameter growth was $1.53 \mathrm{~cm}$ which was the biggest growth compared to the first and second year's growth.

Table 1 also indicates that P6 treatment had the greatest MAI (Mean Annual Increment) in diameter and height compared with the other treatments. This P6 diameter growth value was better than the annual increment of Khaya in Cikampek Research Forest $(1.36 \mathrm{~cm} / \mathrm{yr})$ and Pasir Hantap Research Forest $(1.43 \mathrm{~cm} / \mathrm{yr})$. For the height growth, all treatments in this research forest showed a greater MAI than in Cikampek (52 cm/yr) and Pasir Hantap (61 cm/yr) (Mindawati and Tiryana, 2002). Although both sites have similar soil fertility and rainfall rate with the Carita Research Forest the P6 vertical mulch application showed the ability to accelerate Khaya growth. This treatment was able to accelerate height and diameter growth while P12 treatment indicated good height growth but moderate diameter growth. To determine the treatments' effect on stem height and diameter, Analysis of Variance was done as shown in Table 2.

Table 2. Analysis of Variance of height for each observation year

\begin{tabular}{lcccc}
\hline \multirow{2}{*}{ Variance source } & Free degree & \multicolumn{3}{c}{ Mean square } \\
\cline { 3 - 5 } & 2 & 2006 & 2007 & 2008 \\
\hline Treatment & 2 & $0.04^{*}$ & $0.01 *$ & $0.1^{*}$ \\
Block & 4 & 18.27 & 58.72 & 308.26 \\
Error & 4 & 0.02 & 0.0075 & 0.0225 \\
\hline
\end{tabular}

Remark $*$ significant difference at $5 \%$ level 
This variance analysis revealed that the different distance of the vertical mulch gave significant variability in the plant height in each observation year. To find the difference among the treatments, the analysis was continued using LSD test and the result is listed in Table 3.

Table 3. Least significant difference test of height variable

\begin{tabular}{cccc}
\hline \multirow{2}{*}{ Treatment } & \multicolumn{3}{c}{ Mean height $(\mathrm{cm})$} \\
\cline { 2 - 4 } & $2006\left(\mathrm{LSD}_{0.05}=0.30\right)$ & $2007\left(\mathrm{LSD}_{0.05}=0.18\right)$ & $2008\left(\mathrm{LSD}_{0.05}=0.63\right)$ \\
\hline $\mathrm{P}_{0}$ & $89.7 \mathrm{a}$ & $199.2 \mathrm{a}$ & $302.4 \mathrm{a}$ \\
$\mathrm{P}_{6}$ & $94.6 \mathrm{~b}$ & $208.0 \mathrm{~b}$ & $322.2 \mathrm{~b}$ \\
$\mathrm{P}_{12}$ & $91.8 \mathrm{c}$ & $203.1 \mathrm{c}$ & $316.2 \mathrm{c}$ \\
\hline
\end{tabular}

Remark: average values in the same coloum followed by different letter indicate significant difference

The test results showed that vertical mulch application with $6 \mathrm{~m}$ distance channel produced the best height rate. On the last measurement, P6 height was $7 \%$ higher compared to the control. Mulching is one of the vertical soil conservation techniques that are expected to provide additional input of organic material for plants. In this research, $6 \mathrm{~m}$ distance of vertical mulch gave a better effect than the $12 \mathrm{~m}$ and the control. It could be explained by better supply of organic matter with $6 \mathrm{~m}$ channel distance. In addition, $6 \mathrm{~m}$ distance was effective in reducing soil nutrient losses, as will be discussed in another section.

Similar fact was also found in the diameter variable. Analysis of variance as shown in Table 4 shows that significant effect of treatment was found in 2007 and 2008 observation years, whereas in 2006 the application effect was not yet significant.

Table 4. Analysis of variance of diameter for each observation year

\begin{tabular}{lcccc}
\hline \multirow{2}{*}{ Source } & \multirow{2}{*}{$\begin{array}{c}\text { Degree of } \\
\text { Freedom }\end{array}$} & \multicolumn{3}{c}{ Mean square } \\
\cline { 3 - 5 } & 2006 & 2007 & 2008 \\
\hline Treatment & 2 & 0.01 & $0.003^{*}$ & $0.01^{*}$ \\
Block & 2 & 0.26 & 0.80 & 1.04 \\
Error & 4 & 0.25 & 0.0035 & 0.01 \\
\hline Remark * = significant difference at 5\% level
\end{tabular}

Least Significant Difference test results presented in Table 5 shows that the P6 treatment significantly produced the bigger diameter in 2007 and 2008.
Table 5. Least significant difference of diameter for years 2007 and 2008

\begin{tabular}{ccr}
\hline \multirow{2}{*}{ Treatment } & \multicolumn{2}{c}{ Average diameter $(\mathrm{cm})$} \\
\cline { 2 - 3 } & $\begin{array}{r}2007(\mathrm{LSD} \\
=0.13)\end{array}$ & $\begin{array}{r}2008(\mathrm{LSD} \\
=0.31)\end{array}$ \\
\hline $\mathrm{P}_{0}$ & $1.98 \mathrm{a}$ & $3.63 \mathrm{a}$ \\
$\mathrm{P}_{6}$ & $2.99 \mathrm{~b}$ & $4.76 \mathrm{~b}$ \\
$\mathrm{P}_{12}$ & $2.69 \mathrm{c}$ & $3.90 \mathrm{c}$ \\
\hline
\end{tabular}

Remark: values followed by different letter indicate significant difference

The test results showed that vertical mulch application with $6 \mathrm{~m}$ distance between the channels produced the best diameter rate. At the end of the observation, the $\mathrm{P} 6$ treatment resulted in $31 \%$ greater diameter growth compared to the control, whereas the P12 treatment provided only $7 \%$ bigger diameter increment compared to the control. The research showed that mulching technique provided additional input of organic material for plants. The $6 \mathrm{~m}$ distance of vertical mulch gave a better diameter growth than the 12 $\mathrm{m}$ one and the control. It can be explained by better supply of organic matter in channels with 6 $\mathrm{m}$ distance. In addition, $6 \mathrm{~m}$ distance was effective in reducing soil nutrient losses.

\section{B. Runoff and Erosion}

Tabulation of runoff and erosion data during the first year of the study is listed in Table 6 . 
Table 6. Runoff and erosion for each treatment

\begin{tabular}{ccc}
\hline Treatment & $\begin{array}{c}\text { Runoff } \\
(\mathrm{mm} / \mathrm{ha} / \mathrm{yr})\end{array}$ & $\begin{array}{c}\text { Erosion } \\
\text { (ton/ha/yr) }\end{array}$ \\
\hline $\mathrm{P}_{0}$ & 1654.29 & 4.6 \\
$\mathrm{P}_{6}$ & 407.56 & 2.9 \\
$\mathrm{P}_{12}$ & 978.42 & 3.2 \\
\hline
\end{tabular}

Compared to the control, the vertical mulch application with $6 \mathrm{~m}$ and $12 \mathrm{~m}$ channel distances were able to control runoff and erosion. P6 treatment reduced runoff by $75 \%$ and erosion by $37 \%$ compared to the control, whereas in the P12 treatment the runoff and erosion decreased by $41 \%$ and $30 \%$ of control, respectively. Closer channel distance of P6 was more effective in controlling runoff and erosion. Vertical mulch played a role in accommodating and infiftrating the runoff. Excess water that was not absorbed in a vertical mulch became runoff with a lower velocity flow and was accommodated in the next vertical mulch channel. Increased infiltration capacity of the channel due to water absorption of vertical mulch did not only occur at the base of the channel but also on the channel walls. In addition, the presense of soil ridge on the upper part of the vertical mulch channel reduced runoff velocity before it was accomodated into the channel. By decreasing the runoff velocity, the power of water flow in the eroded soil can be suppressed. In addition, a vertical mulch channel is functioning as a container that can hold sediment which is the result of erosion on the upper part of the land. Along with the organic compost, as decomposition's result of organic waste, the sediment can be returned to the field to maintain soil fertility.

\section{Nutrient Losses}

Nutrient in the soil, especially on the surface layer (top soil) are vulnerable to losses through runoff and erosion. Soluble nutrients in the water is carried along by runoff, as well as the existing nutrients in the soil particles will be drifted away during erosion process and deposited as sediment. Chemical analysis of water and sediment samples from erosion plots indicated the amount of nutrient losses through runoff and erosion as shown in Table 7.

Table 7. Nutriant loss (kg/ha/year) through runoff and erosion

\begin{tabular}{ccccccc}
\hline \multirow{2}{*}{ Nutrient } & \multicolumn{3}{c}{ Through runoff } & \multicolumn{3}{c}{ Through erosion } \\
\cline { 2 - 7 } & $\mathrm{P}_{0}$ & $\mathrm{P}_{6}$ & $\mathrm{P}_{12}$ & $\mathrm{P}_{0}$ & $\mathrm{P}_{6}$ & $\mathrm{P}_{12}$ \\
\hline $\mathrm{N}$ & 7.95 & 1.25 & 2.89 & 1.25 & 0.95 & 0.95 \\
$\mathrm{P}$ & 1.93 & 0.75 & 1.22 & 0.0003 & 0.0003 & 0.0003 \\
$\mathrm{~K}$ & 2.90 & 0.85 & 1.59 & 0.39 & 0.28 & 0.38 \\
$\mathrm{Ca}$ & 6.20 & 0.61 & 2.12 & 0.53 & 0.39 & 0.48 \\
$\mathrm{Mg}$ & 0.71 & 0.17 & 0.32 & 0.45 & 0.31 & 0.38 \\
$\mathrm{Na}$ & 0.52 & 0.22 & 0.35 & 0.29 & 0.16 & 0.21 \\
\hline
\end{tabular}

Table 7 shows that the greatest nutrient losses occured either through runoff or erosion was in the control plot. Loss of N, P, K, and Ca elements were much larger in runoff than in erosion, while the $\mathrm{Mg}$ and $\mathrm{Na}$ elements were also found greater in the runoff, but in the sediment there was not much difference. Kasdi et al. (2007) stated that N, $\mathrm{P}$ and $\mathrm{K}$ as the major important nutrient for crop production have its own characteristics against transport by runoff. Due to their mobility, $\mathrm{N}$ and
$\mathrm{K}$ are relatively easy to leach compared with $\mathrm{P}$, so those nutrients are easy to be transported by water through the runoff process. Since N, P, and K are incorporated and adsorbed in the soil materials especially in clay particle, loss of those nutrients can not be avoided until erosion can be controlled by conservation techniques. In this research, a vertical mulch treatment played the role of controlling the runoff and had been able to suppress the loss of nutrients. Similarly, the 
nutrients carried by the sediment particles was caught by the vertical mulch so that soil fertility could be maintained. P6 treatment was better than P12 or control because it was effective in minimizing the loss of soil nutrients through lower runoff and soil erosion.

Table 7 shows that the greatest nutrient loss due to runoff or erosion in all treatments was nitrogen. In the runoff, $\mathrm{P} 6$ treatment was up to five times more effective than P12 in suppressing loss of $\mathrm{N}$ element, while regarding erosion the loss was reduced by three times. Excessive loss of $\mathrm{N}$ element will inhibit plant growth. In term of physiology, $\mathrm{N}$ element is known as an essential macro nutrient playing an important role in the reduction of nitrate metabolite into ammonia, and ammonia assimilation into glutamic acid in the formation of protein and constituent of plant body (Bailey, 1991). An adequate $\mathrm{N}$ element is required in the formation of protoplasm at the growing points of the plant such as at the roots, so the plant can absorb more nutrients along with the spread of the root tissue (Donahue et al., 1977).

The content of $\mathrm{N}$ in the soil can be improved through the provision of organic materials, through binding/fixation by microorganisms such as the rhizobium, or from precipitation (Schroth and Sinclair, 2003; Bailley, 1991). Application of vertical mulch can be a source of organic matter capable of supplying $\mathrm{N}$ and other essential elements in the soil. Research conducted by Puri and Swamy (2001) showed a significant growth of plant biomass as a result of increased $\mathrm{N}$ in the soil. The biggest biomass contribution is in the leaves, followed by the roots and stems. This fact supports plant growth analysis of Khaya in this study where the best growth was obtained on P6 treatment. Siregar and Pratiwi (1999) stated that by presence of mulch, soil microbial activity will increase and play a role in the decomposition of organic matter. Decomposition results, in addition to increasing nutrient, physically also act as a sponge that can absorb and hold large amount of water so that water storage in the soil becomes more efficient and suppress the runoff. Increased organic matter even in a small amount can improve other soil properties. According to Hardjowigeno (2003), this increment can improve soil structure, porosity, addition of $\mathrm{N}, \mathrm{P}, \mathrm{S}$ and other micro-nutrient element as well as improve the ability to retain water and soil cation exchange capacity.

Availability of additional nutrients from decomposition of mulch depends on the speed of the decomposition of the mulch. According to Widyastuti et al. (1998), a fast decomposition of organic material will be able to supply some nutrients during early plant growth, but may not be able to improve organic matter content and soil physical conditions because the litter material will be quickly washed out. In contrast, plant material that decomposing slowly will provide nutrients, little by little, in a longer time and can improve soil's physical conditions. Hardiwinoto (1991) mentioned that the rate of organic material destruction depends on the activity of soil organisms, environmental conditions (external factor), and the chemical content of an organic material (internal factor).

\section{Yield of Corn}

Corn yield in a year is presented in Figure 2.

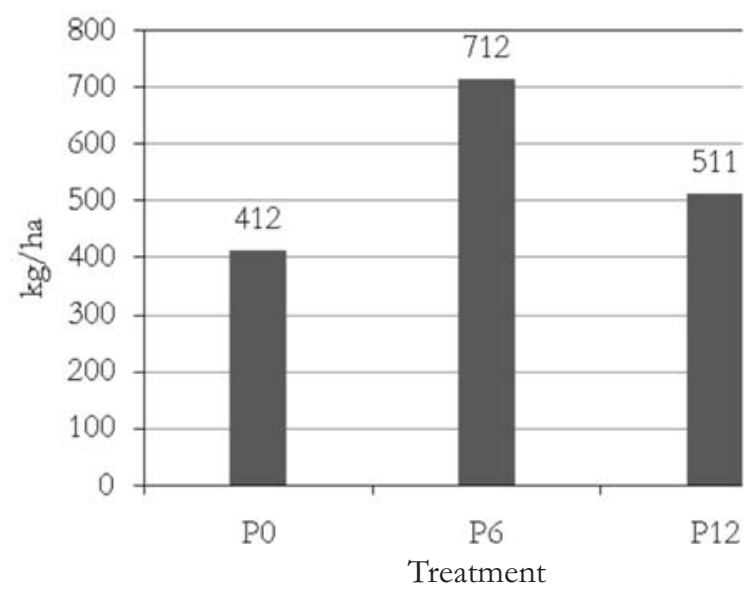

Figure 2. Corn yield in a year 
The largest corn yield was obtained with P6 treatment, while the lowest was the control one, P0. P6 treatment increased the yield by $73 \%$ compared to the control, while in the P12 treatment the increment was only $24 \%$. Treatment effect on corn yield was in line with Khaya growth in the first year and subsequent years. This result was similar with Maass et al. (1988) research revealing that the use of mulch compared to that of grass strips, significantly reduces erosion by more than $90 \%$ and increases crop productivity by almost 30\%. The existence of vertical mulch was expected to provide additional nutrients for the corn crop and suppress nutrient losses, as well as be able to maintain the availability of ground water, especially when entering the dry season. Although corn is a species that does not require much water, but in certain phases such as during the fruit filling phase it will require more water than in other phases. The role of vertical mulch to conserve soil also helps to keep soil moisture due to the presense of organic material in the channel.

\section{E. Costs}

Costs for each component of the treatments per hectare was calculated to find out the total cost required as listed in Table 9.

Table 9. Costs per ha

\begin{tabular}{lrrrc}
\hline \multirow{2}{*}{ Cost component } & \multicolumn{3}{c}{ Cost $(\mathrm{Rp})$} & \multicolumn{1}{c}{ Note } \\
\cline { 2 - 4 } \cline { 2 - 3 } Border measurement & \multicolumn{1}{c}{$\mathrm{P}_{0}$} & \multicolumn{1}{c}{$\mathrm{P}_{6}$} & \multicolumn{1}{c}{$\mathrm{P}_{12}$} & \\
Marker sticks & 250,000 & 250,000 & 250,000 & 1 day x 10 person \\
Planting holes & 125,000 & 125,000 & 125,000 & 1 day x 5 person \\
Planting & 250,000 & 250,000 & 250,000 & 2 day x 5 person \\
Channels and mulch & 125,000 & 125,000 & 125,000 & 1 day x 5 person \\
& 0 & 250,000 & 125,000 & 1 day x 10 person (for P6); \\
Khaya seedling & & & & 1 day x 5 person (for P12) \\
Corn seed & $2,000,000$ & $2,000,000$ & $2,000,000$ & 1000 pcs x Rp 2,000 \\
Tools & 25,000 & 25,000 & 25,000 & 5 kg \\
Others & 125,000 & 125,000 & 125,000 & 1 set \\
Total & 100,000 & 100,000 & 100,000 & Unpredicted cost \\
\hline
\end{tabular}

Remark: labour cost $=\operatorname{Rp} 25,000 /$ day $/$ person

Profitable land management techniques need to be introduced to increase quality and quantity of crops' yield and income of farmers as well as to sustain land resources (Kasdi et al., 2007). Cost calculation for each treatment showed that the differences in costs depend only on the density/distance of the vertical mulch. Cost of implementing P12 treatment was slightly lower (Rp 125,000) than that of P6 as less number of vertical mulch was made per unit area. But by implementing P6 treatment the best result was achieved, namely, better Khaya growth and corn yield as well as lower soil nutrient losses through lower runoff and erosion control mechanism.

\section{CONCLUSION}

1. Application of soil and water conservation technique using 6 meter vertical mulch distance was more effective to increase height and diameter growth of Khaya compared to the 12 meter distance. The growth was incrased by $25 \%$ and $66 \%$ of the control, respectively.

2. Effects of 6 meter distance were better than the 12 meter because it reduced $75 \%$ of runoff and $37 \%$ of erosion. Nutrient losses due to runoff and erosion was reduced up to three and five-times respectively. 
3. Khaya-corn cropping system in combination with $6 \mathrm{~m}$ distance of vertical mulch was capable to produce $712 \mathrm{~kg} / \mathrm{ha} / \mathrm{yr}$ corn or $73 \%$ higher compared to no vertical mulch. This cropping system required $\mathrm{Rp} 3,250,000 /$ ha or was more expensive by $\mathrm{Rp} 250,000 /$ ha than the control (no vertical mulch).

\section{REFERENCES}

Bailey, H.H. 1991. Kesuburan Tanah. Badan Kerja Sama Ilmu Tanah BKS. PTN. Indonesia Bagian Barat.

Balai Penelitian Tanah. 1996. Peta Tanah Tinjau P. Jawa skala 1 : 250.000. Balai Penelitian Tanah, Bogor.

Dariah. A., F. Agus., S. Arsyad., Sudarsono., and Maswar. 2004. Erosi dan aliran permukaan pada lahan pertanian berbasis tanaman kopi di Sumberjaya Lampung Barat. Agrivita 26(1):54-61.

Donahue, R.L., R.W. Miller, and J.C. Shickluna. 1977. Soil: An Introduction to Soils and Plant Growth. $4^{\text {th }}$ ed. Prentice-Hall, Inc, New. Jersey.

Hardiwinoto, S. 1991. Decomposition Procces and Dynamics of nutrient Elements in Decideous Forest of Northen Hokkaido, Japan. Research Bulletins of the College Experiment Forest, 48 (2):325-353.

Hardjowigeno, S. 2003. Ilmu Tanah. Akademika Pressindo. Jakarta. 250pp.

Kasdi, S., T. Vadari, and Sukristiyonubowo. 2007. Nutrient loss by erosion under different land use system in Babon Catchment, Central Java, Indonesia. International Workshop for AUF's networks, Integrated Water and Soil Management. Hanoi, 69 November.

Maass, J.M., C.F. Jordan and J. Sarukhan. 1988. Soil erosion and nutrient losses in seasonal tropical agroecosystems under various management techniques. Journal of Applied Ecology 25:595-607
Mindawati, $\mathrm{N}$ and T.Tiryana. 2002. Pertumbuhan Khaya anthoteca di Jawa Barat. Buletin Penelitian Hutan 632: 4758.

Pratiwi. 2000. Pemanfaatan Bahan Organik Sisa Tumbuhan Untuk Mengurangi Aliran Permukaan, Erosi dan Kehilangan Unsur Hara di Lahan Marjinal Muara Dua, Lampung. Buletin Penelitian Hutan 624:39 50.

Puri, S and S. L. Swamy. 2001. Growth and Biomass Production in Aqadirachta indica Seedlings in Response to Nutrients $(\mathrm{N}$ and P) and Moisture Stress. Agroforestry Systems 51:5768. Kluwer Academic Publishers. Printed in the Netherlands.

Schmidt, F.H. and J.H.A. Ferguson. 1951. Rainfall Type Based on Wet and Dry Period Ratio fo Indonesia with Western New Guinea Verh. No.42. Jawatan Meteorologi dan Geofisika, Jakarta.

Schroth, G. and F.L. Sinclair (Eds). 2003. Trees, Crops and Soil Fertility : Concepts and Research Methods. CABI Publishing, Cambridge.

Siregar, C. A. and Pratiwi. 1999. Pemanfaatan bahan organik dengan teknik mulsa vertikal untuk meningkatkan produktivitas tanah pada hutan tanaman industri. Prosiding Ekspose Hasil-hasil Penelitian Penerapan Konservasi Tanah dan Peningkatan Partisipasi Masyarakat dalam Kegiatan Pengusahaan Hutan. Pusat Litbang Hutan dan Konservasi Alam, Bogor. 11 Februari 1998

Widianto, D. Suprayogo, H. Noveras, R.H. Widodo, P. Purnomosidhi, and M.van Noordwijk., 2004. Alih guna lahan hutan menjadi lahan pertanian: "Apakah fungsi hidrologis hutan dapat digantikan sistem kopi monokultur?” Agrivita 26 (1): 47- 52.

Widyastuti, S.M., Sumardi and H.H. Nurjanto. 1998. Pelepasan unsur hara dalam proses dekomposisi seresah sebagai petunjuk aktivitas mikroorganisme di bawah tegakan Acacia mangium. Buletin Kehutanan, 35: 11-19. 